\title{
Criminal Logistics
}

\section{Globalization, Containerization and Tragedy in Scandinavian Crime Fiction}

\author{
Jakob Stougaard-Nielsen \\ University College London \\ j.stougaard-nielsen@ucl.ac.uk
}

\begin{abstract}
This article investigates how globalized crime fiction is entangled in the infrastructural system of containerization and the production of our global age. My main examples are two widely circulated Danish contributions, namely Peter Høeg's hybrid crime novel, Miss Smilla's Feeling for Snow (1992), and the TV-crime series, The Killing III (2012). Generally considered as contained by the regional moniker of "Nordic noir" these crime narratives can be seen to explore global "criminal logistics" (e.g. transportation networks, containerization, colonial administration, drugs and human trafficking, global capitalism) and their impact on the smaller local scales of states, families and victimized children. Conversely, with reference to David Simon's The Wire (2002-8), the article considers how this "scale bending" between the local and the global is reproduced in the "down-sizing" of Ancient Greek myths and tragedies into the briefest but also most visible of citations on the hull of the ships at the centre of these transnational Danish crime narratives.
\end{abstract}

\section{Keywords}

crime fiction - Scandinavia - The Killing - The Wire - globalization - containerization infrastructure - Greek tragedy

\section{Containerization}

The spread of crime fiction, according to Eva Erdmann, "has taken on topographic proportions that reflect the globalization processes of the late twentieth century ... On the map of the world there are hardly any areas uncharted by crime fiction, hardly any places that have not yet become the setting for 
a detective novel" (13). The ubiquity of crime fiction across languages, nations and cultures and the genre's reliance on and mirroring of wider globalizing processes suggest that:

Detective fiction written in the last decades is more suitable for comparative study than almost any other material, for the tertium comparationis, the fixed course of events in the genre, remains the same-first murder, then suspicion, sometimes a false trail, and in the end, resolution. It is the wide variety of new scenes of the crime that ensures that contrasts exist between the various novels.

ERDMANN 13

If crime fiction has become the paradigmatic model for literature in our globalized age, it might be because its global spread, by way of its generic standards together with its appeal to an international consumer market, resembles and is contained within the infrastructure and logistics of "containerization," which David Harvey has called "one of the great innovations without which we would not have had globalization."

While the metal box of "the standardized shipping container is a simple object," according to Craig Martin, it revolutionized the transportation of goods, taking its proper beginning in the 1950s' United States, demonstrating its efficient global logistics during the Vietnam war and developing rapidly in the 1970 and 8os, simply due to the fact that "its size, shape and form were agreed upon, made standard, and applied on a near-universal basis" (Martin, ch. 2) and that "the entire infrastructure that enabled these boxes to be transported so efficiently was also changed and standardized" (Levinson 9). Today, according to data collected by Alphaliner, more than 6,00o container ships with a capacity to carry twenty million containers operate across the globe, comprising about $90 \%$ of global trade, with the Danish shipping-giant Maersk dominating the market with a $15 \%$ share. $^{2}$ According to Martin (by way of Michel Serres and

1 David Harvey in a panel discussion with Benjamin Buchloh and Allan Sekula at a screening of Noël Burch and Allan Sekula's documentary The Forgotten Space (2010) at the Cooper Union, New York, 15 May 2011. See Burris.

2 Maersk acquired its first container ship in the early 1970s and has since absorbed competitors from many countries including Malcolm McLean's "original" company, which was instrumental in the containerization of world trade, Sea-Land (Levinson 384). This company is interestingly recalled in the Danish TV-crime series, The Killing, to which I shall return, where, in the third season, a central role is given to a major Danish shipping and oil company, thinly disguised as Maersk, called Zee-land. 
Arjun Appadurai), we now live firmly in this "world-object" of the container due to its ability "to produce the global age" and envisage the world as a "global containerscape," "a vast logistical surface of containers being moved in huge container ships before being moved onto rail and road networks" (ch.3).

This article investigates how globalized crime fiction is entangled in the infrastructural system of containerization and the production of our global age. My main examples will be David Simon's The Wire (2002-8), and two widely circulated Danish contributions, namely Peter Høeg's hybrid crime novel, Frøken smillas fornemmelse for sne (Miss Smilla's Feeling for Snow, 1992), and the third season of the TV-crime series, Forbrydelsen (The Killing, 2012). Generally considered as contained by the regional monikers of "Scandinavian crime fiction" or "Nordic noir," as exhibiting dark, cold "localized" varieties of the crime genres, I find these texts particularly interesting for their exploration of contemporary "criminal logistics," which includes, beyond using the standardized genres of crime fiction to "smuggle" local content, explorations of largescale (criminal) infrastructures, such as global transportation networks, colonial administration, drugs and human trafficking, global capitalism and their impact on the smaller local scales of states, families and victimized children. Conversely, I shall consider how this "scale bending" (Smith 193; Heins 606) between the local and the global is reproduced or mirrored in the "down-sizing" of Ancient Greek myths and tragedies, the longue durée of world literature, into the briefest but also most visible of citations on the hull of the ships central to both of these generic Danish crime narratives.

\section{Leaky Containers}

Genres, according to Claire Squires, are crucial components in the literary marketplace (70), sustained by the infrastructure and "the institutional forces that govern the determination and distribution of classification and value" (Frow 147-8). Like the metal boxes that circumnavigate the oceans and drive global trade, the efficacy and functionality of genres in the global marketplace depends on the assumption that textual products can be compartmentalized in accessible stacks of proportionate containers, allowing for speedy distribution of objects. Such is the infrastructure that initiated and sustains global trade; and such assumptions underpin the contemporary market for global literature, particularly when it comes to the popular genres and sub-genres of crime fiction. While the content (e.g. landscapes, customs and proper names) may differ between local expressions, stimulating a global readership's desire for the domesticated exotic, genre fiction circulates seemingly effortlessly between 
languages and markets due to the genres' proximity to what is already known and familiar, to values and norms globally shared. ${ }^{3} \mathrm{~A}$ hardboiled detective novel by Gunnar Staalesen set under the bleak sky of Bergen in the 1980s Norway will be recognizable to readers well acquainted with Raymond Chandler's sunny Los Angeles or with Kenzo Kitakata's suburban Tokyo and its crime-ridden underworld.

However, while genres perform important classifying and distributive functions, allowing readers to navigate book stores, genres, as other categories we use to manage the proliferation and diversity of literary expression (e.g. periods, national literatures), are at best "leaky containers" (Levine, para. 53): they "are not well-defined and stable classes governing objects in a closed set" (Frow 31). Unlike the shipping container itself, "the forms and functions of genre are dynamic, shifting and evolving" over temporal and geographic distances (Shaw 10).

Genres, as Franco Moretti demonstrates in his quantitative studies of the novel in nineteenth-century Britain, rise and disappear in regular "life-cycles," in wave-like patterns of shifts in perceptions of what constitutes "normal literature" in a certain place and time. This is why Moretti thinks of genres as "temporary structures," morphological repetitions of limited duration (Graphs 14), while they are also evolving spatial structures of cultural interferences or compromises between centres and peripheries in the global literary field (Conjectures 56). In Moretti's distant view of the diffusion of the modern novel, waves of foreign forms break down national barriers, interfere with local circumstances leading to transformations of the large-scale global form of the novel.

Wai Chee Dimock's conception of genre as a category presenting a challenge to the ways in which literary history compartmentalizes literatures into discrete periods and national expressions, is helpful here, as she considers genre as based on kinship, as related to "interconnections" rather than "classifications." To Dimock, genres are always "in transit" where likeness is "probabilistic and distributional," rhizomatic, rather than based on direct lines of ancestry (Through Other Continents 74). In such "worlded" perceptions of genre we are returned to the leaky containers of global trade, to the infrastructure rather than the structure of a transnational literary market, but also to Goethe's early vision for a world literature. He famously celebrated the prospect of intensified "international exchange" of ideas and books and its "ever-increasing rapidity"

3 This is Lawrence Venuti's argument in The Translator's Invisibility (2008) concerning the English translation and reception of crime fiction and especially Scandinavian crime fiction. 
(Hoesel-Uhlig 37). Goethe noted that the global interchange of literatures was already in the early nineteenth century driven by changes in transportation infrastructures and communication technologies. His expectation of a "universal world literature" ("allgemeine Weltliteratur") (Werke 41.2, 265) was at least partly to be driven by "vastly facilitated communications" ("durchaus erleichterter Communication") (ibid. 299; Birus 13) and the "constantly spreading activities of trade and commerce" ("immer mehr umgreifende Gewerks- und Handelsthätigkeit") (42.2, 505; Birus 13). ${ }^{4}$

According to Hans Joachim Schrimpf (in his seminal study Goethes Begriff der Weltliteratur), some of the key terms repeated in Goethe's writings that relate to his conception of a universal world literature are "global circulation" ("Weltumlauf") and "global exchange" ("Weltverkehr") (12). His use of these terms reflect his interest in the building of the Panama Canal and the future impact of this global infrastructure on the increased communication between nations. ${ }^{5}$ Goethe predicted that with the growing importance of trade and commerce, "global exchange" ("Weltverkehr"), to the spread of ideas, a global mass literature would rise to prominence and leak out of world literature proper, the Western-European tradition of high-brow literature (Pizer 216-7).

We are now thoroughly at this age of global exchange. According to Pizer, we must realize that "with the globalization of the world economy, a true world literature, which is to say a global literature, is being created" (213). Hierarchies of value still exist between "literary" and "generic" texts, the latter still rendered suspicious by its commercial and popular appeal, by its standardization and conventionality. However, as Katy Shaw has pointed out, supplementing Moretti's wave-theory, all genres can potentially drive change in the wider literary field: "Some genres are revived or go through phases of popularity, while others are resurrected in response to changing social and political and economic conditions" (10). Today's transnational spread of new local variants of

4 Theo D'haen and others have pointed out "the almost seamless analogy Goethe here establishes between the circulation of ideas and that of goods. In fact, of course, ideas also traded as goods, that is to say in the form of 'material' books and periodicals" (D'haen 97).

5 According to Peter Madsen, “Goethe's concept of 'Weltliteratur' was coined at an early stage of globalization; it was, however, intimately linked with global integration as he saw it. In his later years he was fascinated by the prospect of the linking together of the world through the construction of both a Panama Canal and a Suez Canal. Trade was the model for cultural exchange and permeated his metaphors: the word Weltliteratur was analogous to Weltverkehr (global exchange) ... 'Free trade of concepts and sentiments, just as exchange of products and fruits of the earth, will increase the wealth and the general well-being of mankind'" (73). 
standardized crime fiction is not only supported by the realization of Goethe's infrastructural dream of Weltumlauf by way of modern container ships, but also the "temporary structures" of crime fiction and its ability to respond to pressing social conditions produced by global infrastructures and logistics. The dispersed local variants of the "leaky containers" of crime fiction are, in other words, well placed to capture and engage reflexively the globalizing processes as they affect and are reflected in local spaces of transit.

\section{Deep Time and Global Risks in Arctic Thriller}

Peter Høeg's genre-hybrid and postcolonial crime thriller Miss Smilla's Feeling for Snow (1992) was the first truly globalized Scandinavian crime novel as it both enjoyed wide international circulation, predominantly for its setting in an eccentric location, and took the local impact of various processes of globalization as its central theme. The accidental detective Smilla is a GreenlandicDanish glaciologist who becomes involved in the investigation of what she believes to be the murder of a Greenlandic boy, the neighbor's always dirty child, Isaiah. He had occasionally sought out Smilla's reluctant company when his alcoholic mother was unable to care for him. When his lifeless body is found on the snowy ground next to their block of flats in Copenhagen, Smilla does not believe in the police's theory that he had simply fallen from the roof by accident. Noticing subtle characteristics of his footprints in the snow, she believes that Isaiah had been running away from someone he feared more than height. Smilla's investigation into Isaiah's mysterious death turns into an intricate unravelling of colonial history, its effects on contemporary Danish and Greenlandic societies and, not least, an investigation into her own colonial family history, her conflicted hybrid sense of self and loss of cultural identity.

The intricate plot, the wide expanse of temporality and space explored in the novel turns Smilla's investigation essentially into an exploration of crime scenes on disparate yet connected scales. Smilla realizes that the small "catastrophe" of her innocent Greenlandic friend falling to his death is a small-scale version of the larger "forces and catastrophes" connected to the incompatible and fraught historical relationship between the Danish welfare administration and a colonized Greenland, of which she is herself a traumatized victim (Høeg $79)$.

Smilla's scientific knowledge of ice is instrumental in her investigation into Isaiah's death where, particularly in the first part of the novel entitled "The City," she performs as a classical urban, rational or forensic detective with a "feeling" for scales: she "only ha[s] to look at a map once and the landscape 
rises up from the paper" (68). Her ability to navigate the borderless, snowwhite world of the Arctic informs her understanding of a series of events that connects neo-colonial conflicts in 1970s South-East Asia, to Danish colonial exploitation and future global catastrophic risks: "[t] here's nothing 'local' left anymore .... If something happens in Greenland, it's connected to something else in Singapore" (218).

Smilla's investigation uncovers a scientific conspiracy to conceal the presence of a meteor and a deadly parasite deep in the Greenlandic tundra. It is this "prehistoric" parasite, a deadly "arctic worm," which had infested Isaiah who had subsequently been the subject of illicit scientific probing until he ran away from his tormentors. The parasite, which "can live anywhere" (399), poses a catastrophic risk to humanity if Smilla does not succeed in thwarting the scientists' plan to bring the meteor back to Denmark, thereby releasing the parasite into global circulation. In this Gothic figure of a prehistoric parasite, awoken from its eternal frozen slumber, first by a meteor and then by egocentric scientists, the crime thriller adds a further scale connecting deep time with present transnational crimes and a truly apocalyptic future.

As Smilla begins her perilous journey towards the ice cave and the original locus criminis deep in the Greenlandic landscape on board the mythical ship Kronos, the novel shifts in mode from a novel of detection to a claustrophobic science-fiction eco-thriller. With this shift, the social-realistic detective's investigation of a predominantly local condition and history is revealed to implicate wider global conflicts. If the small catastrophe of Isaiah's death opened up wounds in a personal and national colonial history in the detective narrative, the science-fiction thriller investigates the more universal crimes of Western scientific hubris and global drugs trafficking. Tørk Hviid, the Danish scientist who leads the expedition to recover the meteor, is not only a colonial parasite himself, about to commit an environmental crime against humanity, he is already connected to global crimes and the "world trade in heroin" through his past work refining drugs in a laboratory in the jungles on the border between Cambodia and Laos (200). Smilla discovers that Kronos is also used for smuggling heroin to fund the expedition, and in this way global trajectories converge and are contained in this dystopian vessel of global risks.

Kronos is an apt figure for globalization and divine punishment for human scientific hubris. It embodies an after-Babel world in miniature carrying a motley crew, who are, like Smilla, exiles, rootless victims of neo-colonialism with disintegrating identities and languages:

The crew's mess on board the Kronos is a Tower of Babel of English, French, Fillipino, Danish, and German. Urs drifts helplessly among frag- 
ments of languages he has never learned to speak. I sympathize with him. I can hear that his mother tongue is disintegrating. 281

Kronos, then, lives up to its mythological name citing the Titan of Greek mythology who devoured his own children except for one survivor, Zeus; yet, not just in an abstract sense. The police investigator Ravn lost his own daughter in Singapore, where she was working as a consular secretary. Her death was covered up as suicide (218), much like the authorities' attempt to conceal the real reason for Isaiah's death. It turns out that it was Hviid who had pushed her from a balcony, because she was working for the police and was the sole survivor and witness after a raid on his heroin lab. As the global trade of heroin was Hviid's reason for killing Ravn's daughter, so a border-crossing Arctic parasite became the reason for chasing Isaiah to his death. Both of them the children and surviving witnesses to his border-crossing crimes. Miss Smilla's Feeling for Snow has progressed from the local particulars of a crime story about the death of a child, through an investigation into a regional colonial history, to a global environmental science-fiction thriller preoccupied with a critique of science and Western civilization to become, again, in the words of Mary Kay Norseng, "really a novel of nothing but children," a novel of lost, wounded and dead children and parents in mourning (59). Though the correlation between the miniature and monstrous scales of past, present and future crime scenes in this novel are tenuous, they connect in what has eventually become a delocalized, transnational and trans-historical, if not mythic, exposé of the doomed victims of transnational Verkehr, colonial administration, neo-colonial exploitation and scientific hubris.

While Høeg asks us to contain the small-scale local crime and the infected body of a small Greenlandic boy in the macro-scale of drugs trafficking and a global pandemic, to view the local and the global as mutually contaminating scales, the narrative also suggests that we can contain the macroscopic set of recognizable global events in the microscopic citation of Greek mythology in the ship's name, Kronos-a dispassionate God and a substitute for the state institutions, drug dealers and scientists in the novel.

It is clear that we are not dealing with a crime novel whose main contribution to a universal genre is local colour. Høeg's novel is certainly eccentric, but its hybrid form and preoccupation with the global traffic of humans, drugs and parasites does not easily fit within available generic containers, neither does its ambition to scale up the theme of violence against children belong firmly to a national tradition or local circumstances. It is also not strictly a modern adaptation of an Ancient Greek myth, as it merely recalls the name of Kronos to 
activate the global reader's patchy memory of the original myth; however, this is part of Smilla's literary Weltumlauf, amplified by a further recall connecting the myth of Kronos to the Judeo-Christian prophet Isaiah, playing the part of Zeus, embodied in the murdered Greenlandic boy. It is Isaiah's "prophecy" that Smilla has been called to fulfil, a prophecy that calls out the sinners and gives the world to "a little one" who "shall become a thousand, and a small one a strong nation" (Isaiah 60:22).

Dimock has called this practice of citation in popular cultural texts "low epic" ("Low Epic" 631). The downsizing of epic scale, the longue durée, to a single quoted word suggests that readers today do not need to recognize the struggle between Gods and their offspring, the inescapability of fate and the looming apocalyptic threat of the demise of the known world to either understand Høeg's crime novel or the connotation of the epic; perhaps, Dimock suggests by way of Bakhtin, "the affective burden of the epic has remained the most durable burden known to the human species, surviving from prehistoric times into our own simply because we have not evolved very far from those charged origins" (627). Already the Ancient epic, as Dimock reminds us, depended on "citation" and "briefness" as an aid to memory, as a way to efficiently store and "contain" the very large and collective hopes and fears: "It is these reversed proportions," Dimock finally argues, these meetings of scale, "that make the catastrophic briefness of human life not quite catastrophic, saving us from the brute fact of large numbers, rendering back to us a numerically demoted but otherwise undiminished sense of ourselves" (631). In Miss Smilla's Feeling for Snow chaotic criminal logistics, whose catastrophic powers and global risks begin to leak with the death of the small prophet Isaiah, converge in the lowepic citation of Kronos. This reference to Ancient myth is a double gesture of what Dimock calls "reverse telescoping," in which gigantic scales are bent towards the miniature and the scale of the human: i.e. where the global risks of scientific hubris and invisible border-crossing crimes are forced to the surface by the affective response of the "detective" to the serial abuse of children ("the little ones"), and where the late-modern burden of "liquid fears" (Bauman 6) may be contained, at least for a while, in a contemporary hybrid crime novel that sails under the Ancient epic's "flag of convenience."

\section{Indifferent Gods and Containerization in The Wire}

The distant yet proximate kinship between Ancient genres and thoroughly localized contemporary crime fiction was foregrounded by the creator and head writer of the TV series The Wire (нво, 2002-2008), David Simon. The Wire 
is essentially a social-realist police procedural in which a shifting team of hardheaded detectives try to solve crimes and unveil their hidden infrastructures in the post-industrial city of Baltimore. Over its five seasons, the serial explores the drug infested criminal underworld and individual destinies within corrupt and eroding public institutions such as the police force, city hall, the port, the educational system and the media. Although firmly localized in a dystopian yet recognizable contemporary social reality, Simon reveals that they "ripped off the Greeks" in their conception of the series:

We've basically taken the idea of Greek tragedy and applied it to the modern city-state ... What we were trying to do was take the notion of Greek tragedy, of fated and doomed people, and instead of these Olympian gods, indifferent, venal, selfish, hurling lightning bolts and hitting people in the ass for no reason-instead of those guys whipping it on Oedipus or Achilles, it's the postmodern institutions ... those are the indifferent gods. ${ }^{6}$

TALBOT, para. 19

Slavoj Žižek has elaborated on Simon's reference to Greek tragedy by insisting that the celebrated realism of The Wire has less to do with its presentation of an objective lived reality, the naturalistic depiction of the "real miserable life of drug-addicted people in Baltimore," and more to do with what he calls a "subject realism" with deep roots in the social function of Greek tragedy: it is "as if a community ... in this case the community of people of Baltimore wanted to stage their own collective self-representation ... Greek tragedy ... was, you know, a collective event of a polis, a city staging its own self-representation, experiencing its own being, its antagonisms and so on" (Žižek; Rader 176).

Though neither Simon nor Žižek are experts in Ancient Greek, "their reflexive understanding of the parallels between the cultural poetics of Greek tragedy in the polis of Athens and modern Baltimore and the crime series," according to Richard Rader, "agrees with contemporary understandings of the function of tragedy and comedy in the polis" as narrative and social spaces into which Athenians "projected their darkest fantasies, fears and desires (murder, incest, rape, empire, etc.)" (177). Modern crime fiction is a genre that "organizes its narrative around the execution of a process, an orderly and to some

6 David Simon also alluded to Greek tragedy in an interview with Slate magazine: "the guys we were stealing from in The Wire are the Greeks. In our heads we're writing a Greek tragedy, but instead of the gods being petulant and jealous Olympians hurling lightning bolts down at our protagonists, it's the Postmodern institutions that are the gods" (O'Rourke 2006). 
extent standardized set of practices used by law enforcement to detect, deter and investigate criminal activity" (Von Mueller). However, when considering a crime narrative such as The Wire in terms of performative "subject realism", we are called to think of the contemporary police procedural less in terms of its recognizable intra-textual generic form and more as a social text, which extends far beyond its fictional realm in continuation of an Ancient tradition.

To Simon, it is the "postmodern institutions" in The Wire that take the place of the Ancient indifferent gods-institutions borne out of the raw, unencumbered global capitalism that devalues human beings, as depicted in the second season, which centres on the demise of the working class, the devaluing of the longshoremen and their labour (Talbot, para. 6). This season is particularly interesting as the institutional breakdown and the demise of the port's infrastructure is still to some degree a matter of local and national circumstances. However, the largely absent cause of inexorable global processes is revealed when an actual container "leaks" its horrendous hidden cargo of trafficked and murdered sex-trade workers from Eastern Europe smuggled in by "The Greek." While some longshoremen participate in the illicit trade to make up for their loss of work in the post-Fordist economy to ports with better infrastructures elsewhere, it becomes apparent that the inevitable fate of the longshoremen in the port of Baltimore is mirrored in the fate of the dead, nameless bodies stowed away in one of their containers.

The material object and the figure of the container and the neglected infrastructure of the port are essential contexts for and products of what Simon termed "the indifferent gods" of postmodern institutions. The neglected infrastructure in The Wire, which is a sign of the devaluing of the longshoremen, can productively be viewed in light of Bruce Robbins' critical attention to infrastructure as the illuminated commodity's obscure other: the neglected, disinvested, smelly public domain, a domain that remains hidden from public view until the day it malfunctions (Robbins 26). ${ }^{7}$ The "leaky" container is one such malfunction.

As the paradigmatic image of global capitalism, it is also the engine of its own corruption and relatively simple to infiltrate. A mostly invisible yet "representative object of capitalism", the shipping container shares with public infrastructures more generally this trait: "only when the apparent invisibility of these objects is punctured do we really begin to behold their true power" (Martin, ch.3). In The Wire, the disruption of criminal logistics, the illicit use of a shipping container for global trafficking, does not, of course, disrupt or roll

7 See also Rubenstein et al. 
back the systemic violence inflicted upon the longshoremen, the citizens of Baltimore and the trafficked women; yet, it does at least momentarily provide an insight into the hidden infra-structure of the global containerscape and the criminal logistics that infiltrate every corner of the city when left unattended by the public institutions tasked to be their guardian.

If we are not left disempowered by the sheer scale and entanglement of the challenges faced by the doomed characters in The Wire, Simon's "subject realism" may of course provoke in us a desire to preserve, protect, perhaps even love the good(s) proper infrastructures could provide, and contest if not rise, like Zeus, against "the indifferent gods" of postmodern institutions, whose neoliberal divestments have neglected public infrastructures and failed to care for the inevitable victims (Robbins 28).

\section{Indifferent Gods in New Nordic Tv Drama}

What Robbins calls "the smell of infrastructure," the "smell of corrosion, rust and rottenness" that reveals the neglect of public infrastructures, is discernible from the very beginning of the third and final season of the TV-police procedural Forbrydelsen (The Killing; 2007-12). The title sequence shows a montage of corroding, eerie green metal surfaces presumably belonging to the old freight ship Medea lying at anchor in an abandoned, neglected port in Copenhagen harbour.

The title sequence frames a meandering crime plot concentrating on the political drama of an ongoing national election campaign and the recently divorced Zeuthens, whose world disintegrates when their young daughter, Emilie, is kidnapped. Robert Zeuthen is the third-generation owner of the shipping and oil company, Zeeland, which, according to a chief of police, is on the level of the Danish royal family and, according to the frail centre-right coalition, holds the key to the survival of the Danish economy in the aftermath of the 2007-8 global financial crisis. The police investigation into what soon appears to be related crimes, the brutal death of sailors on-board the derelict Medea and the kidnapping of Emilie Zeuthen, is led by a reluctant Sarah Lund, who, at the start of the season is celebrating 25 years at the police force and has applied to be transferred to a desk job with the Operative Planning and Analysis Unit.

The corrosion of the hull of the Medea reflects or contaminates the Danish society from the scale of the global financial crisis to local austerity politics (the sitting prime minister is on the campaign trail with the slogan "everyone must contribute" in an attempt to persuade voters that it is "important to reduce 
expenditures in all corners of society"), to crumbling family relations, where not only the Zeuthen family is under duress; the wound of a lost child, presumably to suicide, will open again in the prime minister's life and Lund's fraught relationship with her son, who is now expecting a child himself, continues to deteriorate in this season. While Lund is (as usual) on her way to leave detective work, she is, due to her inborn inclination for self-sacrifice and dedication to justice, pulled back in to lead the investigation, while she remains under the constant threat of being suspended as political pressure grows and her personal troubles reach a point where they jeopardize her ability to apprehend the kidnapper, who leads the police by the nose down false trails and blind alleys.

All storylines converge in the shipping company Zeeland, the owner of Medea. The prime minister's election campaign and his ability to hold together a weak coalition depend entirely on the support of Zeeland. The company's board of directors are publicly threatening to outsource its operations to Asia as a consequence of the financial climate, but also, one could suggest, as a consequence of the general "globalization of manufacturing," where in this "post-Fordist economy of outsourced, flexible production, geographical location plays an incredibly important role" (Martin, ch. 3). However, as the board of Zeeland makes clear, "sentimental patriotic feelings," as those traditionally held by the Zeuthen family towards Denmark, do not.

The Killing III has much in common with the genre Katy Shaw has defined as Crunch Lit: "a body of writings that collectively function to represent the 2007-8 financial crisis" (8), and, in particular, how this genre presents the ethical conflicts and local social consequences of an ungraspable, entangled global crisis. The fictional prime minister's neoliberal austerity politics have become ubiquitous in today's national and supranational politics. By posing Robert Zeuthen, an icon of the traditional partnership between industry and the modern welfare state, as the welfare state's last hope, it is suggested that the police's (read: the state's) inability to save his child would inevitably lead to extended and deepened austerity measures and the end of the Danish welfare state itself. ${ }^{8}$

While Zeuthen's patriotic feelings may for a while keep Zeeland at the heart of the Danish state, providing taxes, jobs and patronage for disadvantaged, orphaned children through Zeeland's Children's Trust, his own trust in the capabilities of the police start to waver as the search for Emilie and her kidnapper draws out. Through DNA samples the police are, however, able to identify

8 See Nestingen Crime and Stougaard-Nielsen for expanded discussions of Scandinavian crime fiction and the welfare state. 
the kidnapper as the father of a young girl, Louise, who was brutally murdered two years previously in a case that was covered up as suicide. It turns out that he is a former employee of Zeeland, with extensive tactical knowledge of its operations and container shipping. By kidnapping Emilie, he has been able to use the police as an instrument in his personal vendetta against those he believes were involved in the murder and the following cover-up-a cover-up that will eventually implicate, at various degrees of guilt, Zeeland, the Security and Intelligence Service, the Minister of Justice and the Prime Minister's campaign organization.

Investigating the kidnapper's hide-out at the port, the police discover a list of identification numbers for shipping containers, and realize to their horror that he must have sent Emilie as "freight." Back at Zeeland HQ, Zeuthen is being briefed by the company's security services about the police's theory that she might be "on a ship in transit ... possibly in a shipping container." Behind him monitors show a graphic of container ships sailing through the strait between Denmark and Sweden. In the two days that have passed since Emilie was last seen, the container ships could be all over Europe and what has been the backbone of Zeeland's global success, the global traffic of shipping containers, now appears to be used as criminal logistics against Zeuthen, his company and, by association, the Danish state.

The kidnapper's enabling tactical knowledge includes the understanding that "one of the reasons shipping containers move so well is ... that they are perceivably all identical and handled in the same manner the world over. To appreciate this is also to understand their illicit power" (Martin, ch. 4). The kidnapper's name is Loke, a name that refers to the Norse mythological trickster figure, the shape-shifting half-god Loki of Jötnar (giant) descent, who had to suffer the injustice of the god Odin, who threw one of Loki's children, the World Serpent, into the sea where it grew to circumnavigate the world (the truly global figure of Weltumlauf created by Ancient "indifferent gods"). Loke is a master of criminal logistics. He drives and sails numerous vehicles and is fluent in all the Scandinavian languages and "four others." When finally captured, he uses his tactical knowledge to lead the detectives and Zeuthen on a wild goose chase up the coast of Norway in pursuit of a container that turns out to be empty. Loke is a demi-god of containerization, who uses the system he indicts against itself, leading perhaps, if we follow the mythological reference, to Ragnarok, the end of the gods.

Seeing that the police does not have the resources or the man power to search all containers for Emilie, not even those still in the free-port of Copenhagen, Zeuthen activates Zeeland's private security detail and demands that all ships and terminals are checked, while he will duly compensate all affected 
shipping companies. Zeuthen's long-time personal assistant, Niels Reinhardt, notes the impossible scale of the task of tracing a nondescript container that could be anywhere, commenting that simply "paying them won't be enough. We can't buy certainty."

With Zeuthen's desperate decision to employ his private security detail, the police as a state institution is partly suspended, and Zeeland is revealed not as the solution to a state in crisis but as part of the problem. Just as we in the end will witness the revelation of corruption, child molestation and murder in Zeeland's "social responsibility program," the Children's Trust, which has provided Reinhardt with an ample supply of orphaned victims around the world, including Louise, so does Zeuthen's recourse to his private security take part in the processes that are eroding trust in the ability of the state to solve crimes, as his choice represents a wider political "shift from the state to market solutions" ushering in a "neoliberal state" as made for "deviant globalization" (Franco Aas 151). At the free port of Copenhagen, the police are unable to continue their investigation as the harbour is swarming with Zeeland security.

This illustration of the commodification of security, the degradation of state power and the corroding of state legitimacy, is an example of a wider trend in Scandinavian crime fiction in the twenty-first century explored by Andrew Nestingen. He finds that within contemporary genre fiction there is a growing trend of representing a contemporary society where "the neoliberal diminishing of the state's role has eaten into the state's symbolic authority" (Unnecessary 173). One of the effects being that regular police investigators are being replaced by private entrepreneurs such as security workers (e.g. Lisbeth Salander), "entangled in criminal activity, yet morally certain" (ibid.). In The Killing III, it is not the police investigator who bears the sign of state corruption, but instead the shipping company, which pretends to act socially responsible and to continue in its role as the staunch protector of state interests (despite the desire of the board of directors) while obstructing its ability to carry out justice.

The replacement of a socially responsible welfare state with "the indifferent gods" of postmodern, neoliberal institutions in the shape of private trusts and security is, of course, only the surface of The Killing's intricate plotting against the legitimacy of state institutions. The entanglement of a powerful shipping company with the political system, the "outsourcing" of social responsibility to a private company in the face of financial crisis, has already proven to be detrimental to justice as the concerted efforts to cover-up Louise's murder suggests.

In the end, The Killing III reminds us of the central theme of Miss Smilla's Feeling for Snow: it is in the end a story about dead, wounded children. As Gun- 
hild Agger has suggested, the reference to Euripides' tragedy Medea, essentially a story about a violated woman who takes a gruesome revenge on her deceiving husband Jason by killing their children, functions as a banal symbolic echo to the many children in The Killing III, who have become the victims of their parents' neglect and conflicts: the prime minister's son, it turns out, was being coerced by his father's campaign and chased by the Security Services when they found out he had visual evidence of damaging pay-offs given by Reinhardt to the election campaign and an incriminating photo of Reinhardt helping Louise into his car on the day she died. The prime minister's son was chased onto the railroad tracks where he was hit by a train; Emilie was an easy victim for the kidnapper as she was unhappy and angry at her parents because of their quarrelling and eventual divorce; Loke had not been there for his daughter Louise when her mother died, which is why she ended up in Zeeland's Children's Trust; and Sarah Lund's son, of course, refuses to see her due to a lifetime of neglect, though, in the end, there is a glimmer of hope their relationship might be saved, just as the kidnapper in his dying breath tells Lund that Emilie is on board the Medea from where she is recovered and united with her family.

While there might be hope for some of the children, The Killing III ends where it began on the scale of the state. Both of the wounded fathers, Zeuthen and the prime minister, accept in the end the need to cover up Reinhardt's crime, the company and the government's roles in the cover-up, the realities of which would surely lead to scandal and quite possibly the end of Zeeland and the prime minister's aspiration to be re-elected: "Why squabble," as the Minister of Justice coldly summarizes their indifferent ethics, "over an orphaned girl no one would miss?" Foreseeing that the corruption of politics and the justice system by private interests will allow Reinhardt to continue to exploit and murder the trust's children, Sarah Lund, in a surprising final scene, takes the law into her own hands and executes Reinhardt. This is a desperate and impulsive action that will end her career as a detective, send her on the run from the authorities and rob her of the possibility of being reconciled with her son.

It is in many ways a tragic ending, and a tragic portrayal of the fate of justice and social responsibility in a neoliberal state, whose only response to the global financial crisis is to replicate the processes that drove the financial system and the global market to near Ragnarok in the first place. While Loke succeeded momentarily, by illicit means and criminal logistics, to give us a glimpse into the rusty, leaky containers of the smooth systemic operation of wide-spread collusion, the work of the indifferent gods who govern the fate of adults and children alike in The Killing's Copenhagen is similar in kind to those who operated in The Wire's Baltimore. 
Although the global success of Danish TV drama arguably owes a great deal to influences from American Tv drama, the creator and writer of The Killing, Søren Sveistrup, has emphasized a deeper history of influences: ${ }^{9}$

I'm not really interested in doing something normal, about everyday life. I'm more interested in myth - the whole idea of Copenhagen being like Thebes. Copenhagen is captured. There's a big mystery. No one can breathe, no one can move. Sarah Lund is really the old Greek myth, the torch in the darkness trying to liberate the whole system from corruption and damnation.

COLlins, para. 36

Tasked with the promethean or prophetic struggle to throw light on the fates of the most vulnerable in the hands of the indifferent gods of postmodern institutions, whose power appears undiminished in the wake of global crises, detectives such as Smilla and Sarah Lund provide much more than simple local contrast to an otherwise bland, containerized transnational genre. Global crime fiction moves seamlessly within the containerscape of a global literary marketplace, yet reveals its critical potential not simply by coopting local (national) contrast, but by representing and investigating the logistics of scale between local institutions and global infrastructures, between contemporary crime fiction's containment of present fears and anxieties about globalizing forces and the "affective burden" of Ancient epics and tragedies.

\section{Works Cited}

Agger, Gunhild. "Thrillerens Kunst: Forbrydelsen I-III." 16:9, Nov. 2012. Web. 8 Jul. 2016. Alphaliner. "Alphaliner-Top 100." Web. 11 Oct. 2016. Bauman, Zygmunt. Liquid Fear. Cambridge: Polity Press, 2006.

9 According to an article in The New Yorker: "The second thing that revolutionized Danish television was a trip to America. In the mid-nineties, DR sent several of its top executives and producers to Los Angeles, where they visited the sets of 'N.Y.P.D. Blue', 'L.A. Law', and '24.' They returned to Denmark with new concepts: writers' rooms, showrunners, multi-episode series. 'From then on, we were consciously trying to professionalize,' Piv Bernth, of 'The Killing,' said. Gjervig Gram [writer on Borgen] explained, 'We said, We're going to do it the American way, but it took some years to find the Danish way to do it the American way'" (Collins). 
Birus, Hendrik. "The Goethean Concept of World Literature and Comparative Literature." In Comparative Literature and Comparative Cultural Studies. Eds. Steven Tötösy de Zepetnek, West Lafayete, IN: Purdue UP, 2003, 11-22.

Burris, Jennifer. “Forgotten Spaces.” Online video clip, 29 May 2011. 11 Oct. 2016.

Collins, Lauren. "Danish Postmodern: Why are so many people fans of Scandinavian TV?" The New Yorker, 7 Jan. 2013. Web. 11 Oct. 2016.

D'haen, Theo. The Routledge Concise History of World Literature. London: Routledge, 2012.

Dimock, Wai Chee. Through Other Continents: American Literature Across Deep Time. Princeton: Princeton UP, 2009.

Dimock, Wai Chee. "Low Epic." Critical Inquiry 39 (2013), 614-31.

Erdmann, Eva. "Nationality International: Detective Fiction in the Late Twentieth Century." In Investigating Identities: Questions of Identity in Contemporary International Crime Fiction, eds. Marieke Krajenbrink and Kate M. Quinn. Amsterdam: Rodopi, 2009, 11-26.

Franco Aas, Katja. Globalization and Crime, 2nd ed. London: Sage, 2013.

Frow, John. Genre. London: Routledge, 2015.

Goethe, Johann Wolfgang von. Werke. 133 vols. Weimar: Böhlau, 1887-1919.

Heins, Matthew. "Infrastructure, the shipping container, and the globalization of American space." ARCC Conference Repository, o (2011): 603-6og. Web. 11 Oct. 2016.

Hoesel-Uhlig, Stefan. "Changing Fields: The Directions of Goethe's Weltliteratur." In Debating World Literature. Ed. Christopher Prendergast. London: Verso, 2004, 2653 .

Høeg, Peter. Miss Smilla's Feeling for Snow. Trans. F. David. London: Vintage, 2005.

Levine, Caroline. "On Infrastructuralism, or the Tempo of Institutions." In Periodization: Selected Essays from the English Institute. Ed. Virginia Jackson. Cambridge, MA: English Institute in collaboration with the American Council of Learned Societies, 2010. Web. 8 Jul. 2016.

Levinson, Marc. The Box: How the Shipping Container Made the World Smaller and the World Economy Bigger. Princeton: Princeton UP, 2016.

Madsen, Peter. "World Literature and World Thoughts: Brandes/Auerbach." In Debating World Literature. Ed. Christopher Prendergast. London: Verso, 2004, 54-75.

Martin, Craig. Shipping Container. London: Bloomsbury, 2016 [Kindle edition].

Moretti, Franco. “Conjectures on World Literature." New Left Review 1 (2000), 54-68.

Moretti, Franco. Graphs, Maps, Trees: Abstract Models for Literary History. London: Verso, 2007.

Nestingen, Andrew. "Unnecessary Officers: Realism, Melodrama and Scandinavian Crime Fiction in Transition." In Scandinavian Crime Fiction. Eds. Nestingen and Paula Arvas. Cardiff: University of Wales Press, 2011, 171-84. 
Nestingen, Andrew. Crime and Fantasy in Scandinavia: Fiction, Film, and Social Change. Seattle: University of Washington Press, 2008.

Norseng, Mary Kay. "A House of Mourning: Frøken Smillas fornemmelse for sne." Scandinavian Studies 69 (1997), 52-84.

O'Rourke, Megan. "Behind The Wire: David Simon on where the show goes next." Interrogation, Slate, 1 Dec. 2006. Web. 8 Jul. 2016.

Pizer, John. “Goethe's 'World Literature' Paradigm and Contemporary Cultural Globalization." Comparative Literature $5^{2}$ (2000), 213-227.

Rader, Richard. "The Ethics of Greek Drama." In A Companion to Greek Literature. Eds. Martin Hose and David Schenker. Malden, MA: Wiley Blackwell, 2016, 175-189.

Robbins, Bruce. "The Smell of Infrastructure: Notes toward an Archive." boundary 234 (2007), 25-33.

Rubenstein, Michael, Bruce Robbins and Sophia Beal. "Infrastructuralism: An Introduction." Modern Fiction Studies 61 (2015), 575-86.

Schrimpf, Hans Joachim. Goethes Begriff der Weltliteratur: Essay. Stuttgart: Metzler, 1968.

Shaw, Katy. Crunch Lit. London: Bloomsbury, 2015.

Simon, David. The Wire, Season 2. нво, 2003.

Smith, Neil. "Scale Bending and the Fate of the National." In Scale and Geographic Inquiry: Nature, Society, and Method. Eds. Eric Sheppard and Robert B. McMaster. Malden, MA: Wiley Blackwell (2004), 192-212.

Squires, Claire. Marketing Literature: The Making of Contemporary Writing in Britain. Houndmills: Palgrave, 2009.

Stougaard-Nielsen, Jakob. Scandinavian Crime Fiction. London: Bloomsbury, 2017.

Sveistrup, Søren. Forbrydelsen III. Danmarks Radio. Copenhagen, 2012.

Talbot, Margaret. “Stealing Life: The Crusader behind 'The Wire.” Profiles, New Yorker, 22 Oct. 2007, 150-63. Web. 8 Jul. 2016.

Venuti, Lawrence. The Translator's Invisibility: A History of Translation, 2nd ed. London: Routledge, 2008.

Von Mueller, Eddy. "The Police Procedural in Literature and on Television." In The Cambridge Companion to American Crime Fiction. Ed. Catherine Ross Nickerson. Cambridge: Cambridge up 2010, 96-109.

Žižek, Slavoj. "The Wire or the clash of civilisations in one country." Lecture at The Birkbeck Institute for the Humanities, 24 Feb. 2012. Web. 8 Jul. 2016. 